\title{
Indonesians' Perceptions of Auto Parts Remanufactured in China: Implications for Global Remanufacturing Operations
}

\author{
Kenichiro Chinen ${ }^{1}$ and Mitsutaka Matsumoto ${ }^{2, *(D)}$ \\ 1 College of Business Administration, California State University, Sacramento, CA 95819, USA; \\ chinen@csus.edu \\ 2 Advanced Manufacturing Research Institute, National Institute of Advanced Industrial Science \\ and Technology (AIST), Tsukuba 305-8564, Japan \\ * Correspondence: matsumoto-mi@aist.go.jp
}

check for updates

Citation: Chinen, K.; Matsumoto, M. Indonesians' Perceptions of Auto Parts Remanufactured in China: Implications for Global Remanufacturing Operations Sustainability 2021, 13, 3968 https://doi.org/10.3390/ su13073968

\section{Academic Editors:}

Marc A. Rosen and Zenon Foltynowicz

Received: 10 January 2021

Accepted: 30 March 2021

Published: 2 April 2021

Publisher's Note: MDPI stays neutral with regard to jurisdictional claims in published maps and institutional affiliations.

Copyright: (c) 2021 by the authors. Licensee MDPI, Basel, Switzerland. This article is an open access article distributed under the terms and conditions of the Creative Commons Attribution (CC BY) license (https:/ / creativecommons.org/licenses/by/ $4.0 /)$.

\begin{abstract}
Remanufacturing is a key strategy for achieving a circular economy. One crucial obstacle to remanufacturing is consumers' acceptance (or non-acceptance) of remanufactured products. The current study investigated Indonesian consumers' perceived images of remanufactured auto parts (RAPs) remanufactured in China. Consumers' perception of a target country can be either helpful or damaging for an international business. If China seeks successful remanufacturing operations across national boundaries, it must establish national branding and manage the image of remanufactured products to meet and exceed consumer expectations in the global market. An online survey with 500 respondents was conducted to examine (1) how basic product knowledge of RAPs influence consumers' perceived risks and benefits, (2) whether consumers' purchase intention of RAPs made in the home country influences their purchase intention of RAPs made in China, and (3) whether the trust in the RAP certification increases purchase intention of RAPs.
\end{abstract}

Keywords: remanufacturing; consumer acceptance; country of origin effect; national brand; structural equation model

\section{Introduction}

Remanufacturing is the process in which a particular product is disassembled and restored by reusing working components and replacing the faulty or depleted components [1]. It reduces pressure on the environment by minimizing the use of raw materials, thus improving the efficient use of limited resources, reducing energy within the production, and decreasing pollutant emission into the environment. Moreover, remanufacturing is an important component of the resource-efficient manufacturing industry. It requires less raw materials than new products do, thus saving material costs, reducing energy requirements and gas emissions to air and water. Economic and social benefits often accompany environmental benefits. For example, remanufacturing provides opportunities for creating highly skilled jobs and contributes to economic growth. In recent years, the global supply chain of remanufacturing has been growing [2]. Remanufacturing is expected to create global product demand, stimulate innovation, create jobs, and increase trade and investment across various products, including car components, computer peripheries, and technology-related equipment [3]. The growth of the remanufacturing industry is also significant in emerging economies, particularly in Asia [4]. Since 2012, more than three million new cars have been sold for five consecutive years in the Southeast Asian (SEA) region [5], and thus, we can expect the growing demand for remanufacturing in this region [6]. Remanufacturing is one of the practical answers to environmental issues such as unsustainable resource use and environmental pollution; therefore, it has been consistently included in the Asia-Pacific Economic Cooperation (APEC) meeting agenda since 2006.

The global remanufacturing industry is led by the motor vehicle parts sector [7], with an estimated growth rate of 7\% in 2018-2026 [8]. The U.S. International Trade Commission 
(USITC) [7] estimates that vehicle parts comprise more than $60 \%$ of total remanufacturing activities. China is the global leader in automobile production, with $28 \%$ of 92 million automobiles produced globally in 2019 [9]. China's remanufacturing industry was formally established in 2008 [7]. Despite China's relatively short history of remanufacturing industry, the Australian Prudential Regulation Authority [10] predicted China to be the most preferred remanufacturing destination in the future because of its increasing opportunities for remanufacturing, demand factors, expected improvement in legislative aspects, and global supplier presence. Therefore, remanufacturing in China is significant for the sector's growth. China is becoming the dominant economic power with justifiable leadership claims in the SEA region. It showed consistent remarkable economic progress, with more than 6\% annual GDP growth between 1991 and 2019 [11]. The immediate impact and aftershock of COVID-19 on the global economy are inevitable. However, China possessed the economic strength to maintain its market leadership positions in the region. Market leaders might lead other firms by market share, price leadership, product innovation, logistics, or marketing promotion [12].

The study of consumer perception is vital as SEA consumers' perceived images toward remanufactured products made in foreign countries influence their acceptance and demand for these products. This study investigated Indonesian consumers' perceived images of remanufactured auto parts (RAPs) made in China. We used the study conducted by Matsumoto et al. [13] in Malaysia, Thailand, and Vietnam as a theoretical framework in this research. This study found a link between basic product knowledge of RAPs and consumers' perceived risks and benefits. Moreover, we determine that the trust in the certification on RAPs would increase the purchase intention of RAPs. The study of consumer perception is important as SEA consumers' perceived images toward remanufactured products made in foreign countries influence their acceptance and demand for these products. Further, we found the link between the purchase intention of RAPs made in Indonesia and those made in China. To our knowledge, studies examining the relationship between nation branding and purchase intentions are limited [13].

The remainder of this paper is organized as follows. First, we provide the theoretical framework and study questions. Second, we present the methodology, followed by the results of the data analysis. Lastly, we offer findings of research and implications.

\section{Literature Review and Hypotheses}

Remanufacturing is deeply rooted in various products because the concept of remanufacturing has existed in our society from the beginning of the industrial era [14]. However, not many scholars examined the market issues of remanufacturing [15-17]. Understanding antecedent factors of consumer decisions, such as consumers' attitudes, is crucial for marketers' remanufacturing industry. However, only a few studies examined the perceptions of remanufactured products. For instance, Hazen et al. [18] studied how consumers' tolerances and product judgments influence their willingness to pay regarding remanufactured products. Using the theory of planned behavior as a framework, Wang et al. [19] investigated factors that influence consumers' intentions to buy remanufactured products in China.

Meanwhile, Jiménez-Parra et al. [16] studied the remanufactured computer market to identify influencing purchase intention factors in Spain. Sundin et al. [20] conducted cross-cultural interviews in the USA and Sweden. They identified that the following three factors cause the U.S. remanufacturing business's success: cultural behavior, closeness to the circular market, and focus placed on price. Other researchers examined remanufacturing from policy and market barrier perspectives [21-23]. However, limited research included consumer perceptions and behaviors toward remanufactured products made in foreign countries [13].

\subsection{National Image in Global Remanufacturing Operations}

Globalization, or the integration process, led growth in trade and investment between SEA countries to be remarkably faster at present than in the past decades and centuries. International trade spoiled consumers for choices [24]. The remarkable growth due to 
globalization still holds despite the issues of protectionism among the SEA region (e.g., the refusal of Malaysia to reduce tariffs on imported cars until 2005 to protect a local car manufacturer, and the refusal of the Philippines to reduce tariff rates on chemical products and rice until at least 2020). The reputations of countries "function rather like the brand images of companies and products that they are equally critical to the progress, prosperity, and good management of those places" [25]. Nakra [26] claimed that nation branding is becoming ineffective or unclear because of the integrated global supply chains. However, the Mexican avocado industry has been executing successful nation-branding strategies via the Super Bowl commercial in the U.S. market since 2015. Meanwhile, for China, the national image has become more important recently as it competes with emerging SEA economies. An unbranded nation may lose economic and political exposure in the media; thus, image and reputation are becoming integral parts of nation-branding strategies [27].

The theory that connects consumers' beliefs and behavior encouraged researchers to examine how the nation brand influences consumers' perceptions, choices, and buying behaviors [28-34]. They found a direct effect of product evaluation on purchase intention. However, the influence of nation branding on consumers' buying behaviors with remanufactured products remains underexplored. Hamzaoui-Essoussi and Linton [35] investigated the role of product category, perceived risk, and brand name in shaping consumers' purchase behaviors. Meanwhile, Matsumoto et al. [36] studied how perceived product quality affects consumers' willingness to purchase remanufactured parts in SEA countries.

\subsection{Product Knowledge, Perceived Benefits, and Purchase Intention}

Perceived product knowledge combines tangible and intangible knowledge and consumer perception toward a product [37]. Consumers' purchase intentions are strongly influenced by their perception $[3,13,19,36,38]$. If consumers know remanufactured products, they tend to understand that the quality and performance of both new and remanufactured parts are essentially the same. Moreover, they tend to identify the benefits and risks of remanufactured products [39].

Some researchers demonstrated increased energy usage in the remanufacturing supply chain process, including inbound and outbound transportation and operation processes [40-42]. However, researchers identified economic, environmental, and social benefits of remanufacturing, including waste and landfill reduction [43], energy-saving [44], and raw materials [17], and air pollution improvement. Ayres et al. [45] demonstrated a higher demand for remanufactured (reconditioned) copiers. Today, the "green corporate" image encourages the firm to include the sustainable plan in their business mission and objectives and create values for their corporate brand through sustainable strategies. For example, IKEA recently announced a new business model of reuse, refurbishment, recycling, and remanufacturing. They modularize products for easy dismantling and remanufacture their used furniture when their used products are not considered functional [46]. Like IKEA, some companies incorporate information about their carbon footprints and business policies in their sustainable business strategies.

If consumers are familiar with remanufactured products, they know the quality of RAPs is quasi-same as new products. The present study identifies that consumers who perceive risks of remanufactured goods concerning performance, features, product life, and serviceability are not willing to accept remanufactured products [17,47-49]. Consequently, their purchase intention of remanufactured products is lower [50]. We hypothesize that consumers who are familiar with remanufactured products can distinguish remanufactured products from new ones and are aware of both benefits and risks associated with remanufactured products. Accordingly, we established the following hypotheses:

Hypothesis 1 (H1). Consumers' product knowledge negatively influences their perceived risks of RAPs.

Hypothesis 2 (H2). Consumers' product knowledge positively influences the perceived benefits of RAPs. 
Hypothesis 3 (H3). Consumers' perceived risks negatively influence their purchase intention of $R A P s$ remanufactured in their home country.

Hypothesis 4 (H4). Consumers' perceived benefits positively influence their purchase intention of $R A P s$ remanufactured in their home country.

\subsection{Direct and Indirect Effects of Purchase Intention}

Researchers found a negative association between high perceived risk and consumers' purchase intentions [1,17-19,35,47,49]. They also found a positive association between perceived benefits of RAPs and consumers' purchasing intentions [36]. Guiot and Roux [51] concluded that consumers consider secondhand goods (e.g., computers and televisions) as high-risk and suggested the need for warranties or certification to reduce perceived risks to increase sales of secondhand items.

Consumers who are aware of remanufacturing can identify economic, social, and environmental benefits and risks of RAPs [19]. In general, quality certification allows consumers to purchase products confidently. A leading cause of consumers' perceived risks of RAPs is their inability to verify the quality of remanufactured products before purchasing $[13,17]$. Certification by reliable organizations offers trusted guidelines for the remanufactured products [21] or remanufacturing processes and can "reduce the frequency and mitigate consequences of market failures" [52]. Wang et al. [21] observed interactions between certification and environmental benefits on consumers' trust in remanufactured automobile parts.

According to Kotler [53], "buyers make distinct evaluations of brands based on their country of origin" (p. 189). The extent of nation branding varies with the type of product. Through the mechanism of international trade and logistics technology, the variety of products available in global markets has increased. However, many consumers do not have time to learn much about products, mainly when made in other countries. They often are required to make a purchase decision from the complexity of global products. These consumers are armed with a few simple information cues, but they are not entirely cognizant of and do not always acknowledge these cues [54].

In the past several decades, China has received significant investments from global investors seeking a higher investment return. With its cheap workforce, China established itself as a large cluster manufacturer of automobiles. Renowned foreign automobile manufacturers invested in China to produce cars for domestic and international markets, demonstrating China's ability to mass-produce products. In 2010, China became the world's second-largest economy. In Japan's case, it was still considered a developing country 50 years ago, in which "Made in Japan" products were popularly perceived as cheap and produced by sweated labor. In the 1970s, the stereotypes of Japanese products continued to be weak. Only a few Japanese products, such as the Honda motorcycle and the Sony transistor radio, "obtained their popularity in the US market by being first introduced to less-stereotyped consumers such as college students" [55] (p. 89). These products exhibited a competitive advantage because they were new to the market and, therefore, not burdened with the established stereotyped Japanese product image. Following the teachings of quality gurus like W. Edwards Deming [56] and commitment to "Kaizen" or continuous improvement [57], Japan's image was eventually established as a very advanced, innovative, and leading country in producing top-quality consumer products by the mid-1980s [54].

As the Chinese remanufacturing market evolves from a repair-centric to serviceoriented business [36] and as the government relaxes its policies, remanufactured parts are emerging as the most feasible and practical option. As long as global consumers accept products with a "made in China" label, China can become a preferred destination for remanufacturing in the future [58]. Fortunately, the rapid economic development of China, in addition to visible and respectable global brands (e.g., Alibaba, Huawei, Hisense, and ByteDance), may have upgraded the image of "made in China" products recently. Con- 
sumers in global markets have been well-exposed to products "made in China," especially for the last few decades, suggesting a significant demand for the products. Therefore, it is reasonable to assume that Indonesian consumers who rate RAPs remanufactured in Indonesia higher may also evaluate RAPs remanufactured in China higher. We propose the following hypotheses:

Hypothesis 5 (H5). Consumers' purchase intentions of RAPs remanufactured in China are positively influenced by their purchase intention of RAPs remanufactured domestically.

Hypothesis 6a (H6a). Consumers' purchase intentions of RAPs remanufactured domestically are positively influenced by their trust in certified RAPs.

Hypothesis $\mathbf{6 b} \mathbf{( H 6 b ) . ~ C o n s u m e r s ' ~ p u r c h a s e ~ i n t e n t i o n s ~ o f ~ R A P s ~ r e m a n u f a c t u r e d ~ i n ~ C h i n a ~ a r e ~}$ positively influenced by their trust in certified RAPs.

Hypothesis 7a (H7a). Consumers' purchase intentions of RAPs remanufactured domestically negatively mediate the relationship between their perceived risks of RAPs and purchase intentions of $R A P$ s remanufactured in China.

Hypothesis $7 \mathbf{b}$ (H7b). Consumers' purchase intentions of RAPs remanufactured domestically positively mediate the relationship between their perceived benefits of RAPs and purchase intentions of RAPs remanufactured in China.

\section{Method}

\subsection{Scope of Products and Countries}

The present study focuses on consumers' perceived images of RAPs made in Indonesia. We selected Indonesia because it is the largest SEA economy and the 16th largest on the global map. The number of vehicles in operation, new or used, has been growing rapidly in SEA countries, thus influencing the RAP demand. The growth rate of RAP industries is inconsistent across SEA countries. We carefully selected Indonesia because a solid establishment of the auto parts remanufacturing sector does not exist in many SEA countries [59].

Moreover, the auto parts sector is selected for this study because it is the largest global remanufacturing industry $[7,14]$. The United States Agency for International Development [60] reports an upward trend of market growth in Indonesia's remanufacturing sector in recent years. We have chosen alternators and starters (A/S) because they are the most symbolic RAPs among many auto parts. If the industry is established, the remanufacturing will offer an additional choice for consumers.

\subsection{Respondents and Translation}

The data used in this study were collected from Indonesia from January to February 2017 through a marketing company. Exactly 500 respondents participated in the survey who met at least one of the following three conditions: 20-69 years old with a driver's license; an owner of at least one primary car; and experience with car repair services or repairing the car by himself/herself. The authors developed four items regarding the "experience" to determine the respondents' levels of expertise in auto parts. Those who met all three criteria were asked to answer further survey questions. Questionnaire items were back-translated [61] to ensure the accuracy and cross-cultural equivalency of the translation.

\subsection{Knowledge, Benefits, Risks, and Purchase Intention}

Scales measuring perception constructs (i.e., knowledge, benefits, and risks) or slightly modified scales used in the study by Wang et al. [19] were adopted. Purchase intention is defined as "(the) individual assessment of future willingness to buy" [19]. The purchase intention constructs in our survey (RAPs made in either Indonesia or China) consist of two questions (each for made in Indonesia and China) used in the studies by Klein [32] 
and Matsumoto et al. [13]. Respondents indicated their intentions for the two questions using a 7-point Likert scale ranging from "strongly disagree" (1) to "strongly agree" (7). Table 1 summarizes the measurement scales used in this study. Trust in certification (by remanufacturer) is excluded from Table 1 because a single-item, dichotomous variable measured it (trust in RAPs certified by remanufacturers is denoted by 1 , and 0 otherwise).

Table 1. Scales of measurement.

\begin{tabular}{|c|c|c|}
\hline Construct & & Element (Seven-Point Likert Scale) \\
\hline \multirow{3}{*}{$\begin{array}{l}\text { Product } \\
\text { knowledge }\end{array}$} & PK1 & I am familiar with the price level of remanufactured A/S compared to that of new A/S. \\
\hline & PK2 & I am familiar with quality of remanufactured A/S compared to that of new A/S. \\
\hline & PK3 & I am familiar with the differences between remanufactured A/S and reused A/S. \\
\hline \multirow{3}{*}{$\begin{array}{l}\text { Perceived } \\
\text { benefits }\end{array}$} & PB1 & Purchasing remanufactured A/S instead of new A/S can lead to resource and energy savings. \\
\hline & PB2 & Purchasing remanufactured A/S instead of new A/S can reduce the adverse effects on the environment. \\
\hline & PB3 & Purchasing remanufactured A/S instead of new A/S can result in lower purchasing costs. \\
\hline \multirow{4}{*}{ Perceived risks } & PR1 & $\begin{array}{c}\text { The quality and the safety of remanufactured A/S is not as good as that of new products, so remanufactured A/S } \\
\text { may pose a higher safety risk (physical risk). }\end{array}$ \\
\hline & PR2 & Purchasing remanufactured A/S may not be a good investment (financial risk). \\
\hline & PR3 & $\begin{array}{c}\text { Remanufactured A/S do not perform and function, as well as new products, so remanufactured A/S may pose a } \\
\text { higher performance risk (performance risk). }\end{array}$ \\
\hline & PR4 & I may have to return to the garage for repairs more frequently if I use remanufactured A/S (time risk). \\
\hline Purchase & PID1 & I am willing to buy remanufactured A/S made in Indonesia. \\
\hline \multirow{3}{*}{ Intention } & PID2 & I am likely to buy remanufactured A/S made in Indonesia. \\
\hline & PICH1 & I am willing to buy remanufactured A/S made in China. \\
\hline & $\mathrm{PICH} 2$ & I am likely to buy remanufactured A/S made in China. \\
\hline
\end{tabular}

\section{Results}

\subsection{Sample Description}

Table 2 presents the summary statistics of demographics such as gender, age, and experience with RAPs. Male respondents represent $62 \%$. Approximately two-fifths of the respondents were younger than 29 years. Moreover, nearly $50 \%$ of the respondents demonstrated purchase experience of RAPs, and about $46 \%$ of the respondents showed no basic skills in fixing a car.

Table 2. Summary statics of sample consumers in Indonesia.

\begin{tabular}{ccc}
\hline & & Frequency \\
\hline \multirow{2}{*}{ Gender } & Male & 311 \\
& Female & 189 \\
\hline \multirow{2}{*}{ Age } & Under 30 & 200 \\
& 30 or over 30s & 300 \\
\hline \multirow{2}{*}{ RAPs purchase experience } & No & 257 \\
& Yes & 243 \\
\hline \multirow{2}{*}{ Self-rated car repair skill } & No & 331 \\
& Yes & 169 \\
\hline
\end{tabular}

\subsection{Measurement Model: Confirmatory Factor Analysis}

Cronbach's $\alpha$ scores of constructs, perceived knowledge, perceived risks, perceived benefits, and purchasing intention (for RAPs made in the home country (i.e., Indonesia) and made in China), all surpassed 0.8, demonstrating solid internal reliability of the scale used in this study (see Table 3). Convergent validity was assessed based on the criterion that the indicator's estimated coefficient was significant on its posited underlying construct factor. Following Fornell and Larcker [62], we used the following three standards to evaluate convergent validity: 
(i) all the indicator factor loadings should be significant and exceed 0.5;

(ii) the construct reliabilities (Cronbach's $\alpha$ ) should exceed 0.8;

(iii) the average variance extracted (AVE) by each construct should exceed 0.5.

Table 3. Convergent validity.

\begin{tabular}{|c|c|c|c|c|c|c|c|}
\hline Construct & Item & Factor Loading & Construct Mean & $\begin{array}{l}\text { Standard } \\
\text { Deviation }\end{array}$ & $\begin{array}{l}\text { Composite } \\
\text { Reliability }\end{array}$ & AVE & Cronbach's $\alpha$ \\
\hline \multirow{3}{*}{ PK } & PK1 & 0.84 & $5.01 *$ & 1.39 & 0.85 & 0.66 & 0.91 \\
\hline & PK2 & 0.78 & & & & & \\
\hline & PK3 & 0.81 & & & & & \\
\hline \multirow{4}{*}{ PR } & PR1 & 0.72 & $4.86^{*}$ & 1.37 & 0.85 & 0.59 & 0.92 \\
\hline & PR2 & 0.69 & & & & & \\
\hline & PR3 & 0.82 & & & & & \\
\hline & PR4 & 0.83 & & & & & \\
\hline \multirow{3}{*}{$\mathrm{PB}$} & PB1 & 0.66 & $4.56^{*}$ & 1.35 & 0.76 & 0.52 & 0.89 \\
\hline & PB2 & 0.70 & & & & & \\
\hline & PB3 & 0.78 & & & & & \\
\hline \multirow{2}{*}{ PI (home) } & PID1 & 0.91 & $4.40 *$ & 1.47 & 0.93 & 0.87 & 0.86 \\
\hline & PID2 & 0.95 & & & & & \\
\hline \multirow{2}{*}{ PI (China) } & PICH1 & 0.92 & $3.72 *$ & 1.57 & 0.95 & 0.90 & 0.84 \\
\hline & PICH2 & 0.97 & & & & & \\
\hline
\end{tabular}

* Significantly different from the neutral point (4) of the scale, $p<0.001$. Note: AVE: Average variance extracted, PK: Product Knowledge, PR: Perceived Risks, PB: Perceived Benefits, PI: Purchase Intention.

The results in Table 3 show that all three conditions for convergent validity were met.

To demonstrate the discriminant validity, the average variance extracted (AVE) for each factor or latent reflective construct (average variance shared between the construct and its indicators) must be greater than its shared variance with any other factor or construct (i.e., the square of the estimated correlation between two constructs), as recommended by Fornell and Larcker [62]. The results summarized in Table 4 demonstrate that the measurement model satisfies the requirement of discriminant validity. Therefore, the results confirm the instrument's satisfactory construct validity.

Table 4. Correlation between the construct.

\begin{tabular}{cccccc}
\hline & PK & PR & PB & PI (Home) & PI (China) \\
\hline PK & 0.66 & & & & \\
\hline PR & 0.23 & 0.59 & & & \\
\hline PB & 0.03 & 0.03 & 0.52 & & \\
\hline PI (Home) & 0.13 & 0.00 & 0.27 & 0.87 & \\
\hline PI (China) & 0.18 & 0.02 & 0.31 & 0.37 & 0.90 \\
\hline
\end{tabular}

Note: Diagonal elements are AVEs. Figures are a square of the correlation between the construct. PK: Product Knowledge, PR: Perceived Risks, PB: Perceived Benefits, PI: Purchase Intention.

\subsection{Structural Model: Structural Equation Analysis}

After confirming the satisfactory fit for the measurement model, we assessed the structural equation model (SEM) and examined the research hypotheses using AMOS version 27. The SEM is an appropriate statistical tool to analyze the structural relationship between latent constructs. We used the SEM because it allows us to estimate the multiple and interrelated dependence between constructs, such as product knowledge, perceived risks, perceived benefits, and purchase intention, in a single analysis. Figure 1 illustrates our hypothesized model for this study. Computing the $\mathrm{R}^{2}$ statistic is the first step in evaluating the structural model. This method shows the amount of variance of the dependent variable 
explained by the predictor model variables. Overall, the model accounted for $40 \%$ of the variance in purchase intention of RAPs remanufactured in China, 31\% of the variance in purchase intention of domestically remanufactured (i.e., made in Indonesia) RAPs, $23 \%$ of the variance in consumers' perceived risks, and 37\% of consumers' perceived benefits. Next, the value of $\mathrm{R}^{2}$ for the model's construct variables exceeds the reference value of 0.1 [63]. With evidence of acceptable fit, we proceeded to test the hypotheses.

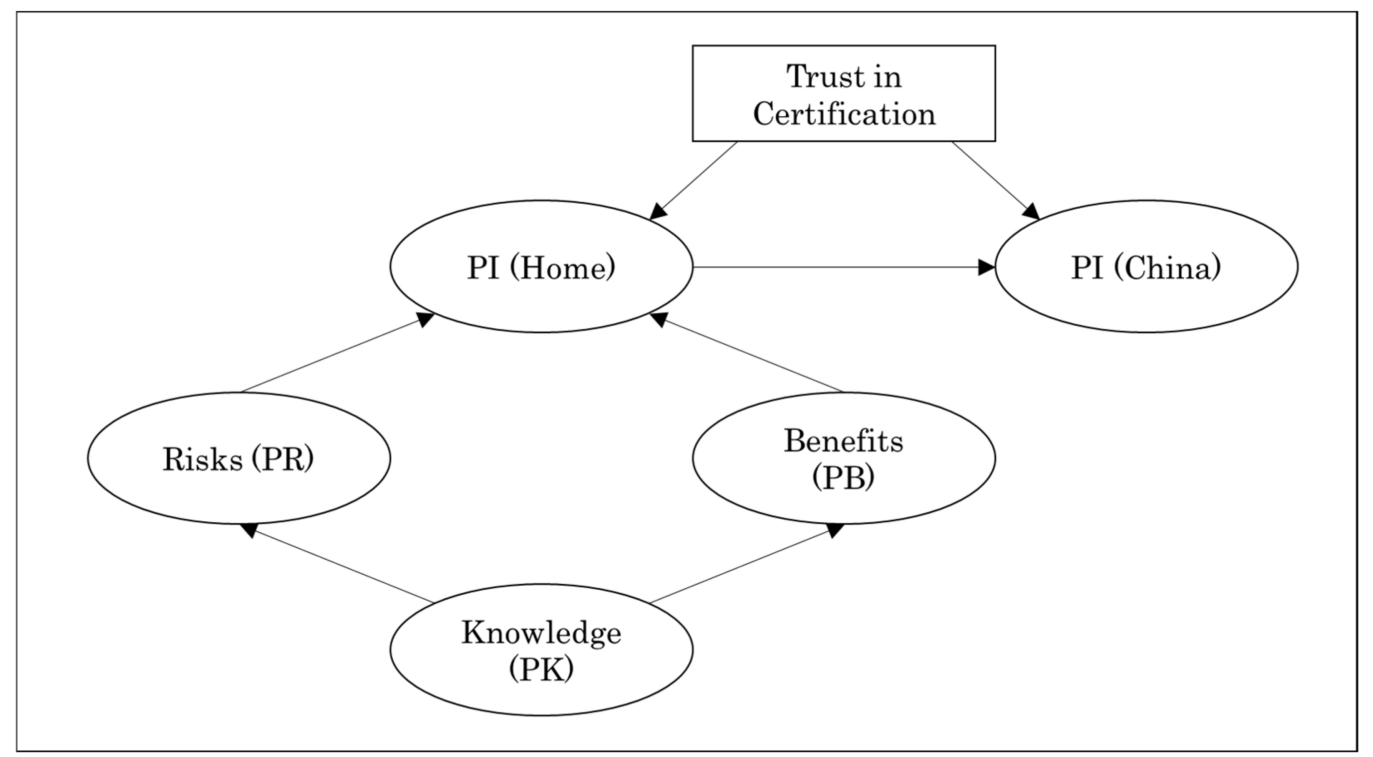

Figure 1. Hypothesized model.

Considering the sample size, we used the Comparative Fit Index (CFI), Tucker Lewis Index (TLI), Normed Fit Index (NFI), and Root Mean Square Error of Approximation (RMSEA) to evaluate the model fit. These fit indexes exceeded the recommended values (CFI, 0.938; TLI, 0.926; NFI, 0.914; RMSEA, 0.068). Our SEM focuses on the direct and indirect effects of consumers' product knowledge, perceived risks and benefits, trust in the certification system, and purchase intentions for RAPs remanufactured in China via purchase intentions of RAPs in the home country (Table 5). The study found a positive relationship between product knowledge and perceived risks; the higher the consumers' perceived knowledge, the greater their perceived risks (H1 is not supported). As predicted by $\mathrm{H} 2$, the study found a positive relationship between product knowledge and perceived risks and perceived benefits (PR $\leftarrow \mathrm{PK}: \beta=0.501, t=9.031, p<0.001 ; \mathrm{PB} \leftarrow \mathrm{PK}: \beta=0.495$, $t=9.936, p<0.001)$. H3 and $\mathrm{H} 4$ examined the direct effects of perceived risks and perceived benefits on the purchase intention of RAPs remanufactured in the home country, that is, Indonesia, in this study. We found statistically significant effects of perceived risks and benefits (PI (Home) $\leftarrow$ PR: $\beta=-.099, t=-1.956, p<0.05$; PI (Home) $\leftarrow$ PB: $\beta=0.800$, $t=9.516, p<0.001)$. This study found that consumers' purchase intentions of RAPs made in China were higher/lower if their purchase intentions of RAPs remanufactured domestically were higher/lower (PI (China) $\leftarrow$ PI (Home): $\beta=0.622, t=14.485, p<0.001$ ). This study observed positive relationships between consumers' trust in certified RAPs and purchase intentions of RAPs remanufactured in both their home country (H6a: PI (Home) $\leftarrow$ CERT: $\beta=0.371, t=2.991, p<0.05$ ) and China (H6b: PI (Home) $\leftarrow$ CERT: $\beta=0.331, t=2.796$, $p<0.05)$. Although no predictions were made concerning gender, our analyses showed that the purchase intention of RAPs remanufactured in China was higher for women than that for men $(\beta=0.462, t=4.019, p<0.001)$. We also found that risk concerns are rated lower by younger consumers than older ones $(\beta=0.299, t=2.853, p<0.05)$. 
Table 5. The result of the structural model: direct effects.

\begin{tabular}{|c|c|c|c|}
\hline$\chi^{2}$ (df, Probability Level) & \multicolumn{3}{|c|}{$372.670(113, p<0.001)$} \\
\hline CFI & \multicolumn{3}{|c|}{0.938} \\
\hline TLI & \multicolumn{3}{|c|}{0.926} \\
\hline NFI & \multicolumn{3}{|c|}{0.914} \\
\hline RMSEA & \multicolumn{3}{|c|}{0.068} \\
\hline Hypothesis & $\beta$ & $t$-value & Support \\
\hline $\mathrm{PR} \leftarrow \mathrm{PK}$ & 0.501 & $9.031 * *$ & H1 (Not supported) \\
\hline $\mathrm{PB} \leftarrow \mathrm{PK}$ & 0.495 & $9.936 * *$ & H2 (Supported) \\
\hline $\mathrm{PI}$ (Home) $\leftarrow \mathrm{PR}$ & -0.099 & $-1.956 *$ & H3 (Supported) \\
\hline $\mathrm{PI}($ Home $) \leftarrow \mathrm{PB}$ & 0.800 & $9.516^{* *}$ & H4 (Supported) \\
\hline PI (China) $\leftarrow$ PI (Home) & 0.622 & $14.485^{* *}$ & H5 (Supported) \\
\hline PI $($ Home $) \leftarrow$ CERT & 0.371 & $2.991 *$ & H6a (Supported) \\
\hline PI $($ China $) \leftarrow$ CERT & 0.331 & $2.796^{*}$ & H6b (Supported) \\
\hline $\mathrm{PR} \leftarrow$ Age & 0.299 & $2.853 *$ & NA \\
\hline PI $($ China $) \leftarrow$ Gender & 0.462 & $4.019^{* *}$ & NA \\
\hline
\end{tabular}

** Statistically significant, $p<0.001 ;{ }^{*}$ Statistically significant, $p<0.05$. PK: Product Knowledge, PR: Perceived Risks, PB: Perceived Benefits, PI: Purchase Intention, CERT (Trust in certified RAPs), Gender: $1=$ male, 2 = female.

To test the effect of a third valuable or mediating variable, we used the bootstrap confidence intervals test method in AMOS version 27. Table 6 shows the results of the mediating effects in this study. In terms of testing mediation using the bootstrap procedure, the null hypothesis (of no indirect effect) is rejected if zero is excluded from the specified confidence interval's lower and upper bounds. In this study, bootstrap analyses with 200 resamples ( $\alpha=0.05$, i.e., the confidence interval at $95 \%)$ did not provide support for the indirect effect of perceived risks on purchasing intention (China) via perceived risks (H7a is not supported; lower bound ( -0.141$)$ and upper bound (0.019), $p=0.114)$. The analysis did not observe the direct effect of perceived risks on purchase intention (China) ( $\beta=0.090$, $t=1.945, p=0.052$ ). By contrast, the analyses observed support for the indirect effect of perceived benefits on purchasing intention for RAPs made in China through purchase intention of RAPs made in the home country (H7b is supported; lower bound $(0.374)$ and upper bound (0.655), $p=0.009$ ). However, the analysis found the direct effect of perceived benefits on purchase intention (China) $(\beta=0.470, t=5.996, p<0.001)$. Thus, we observed a partial mediation.

Table 6. The result of the structural model: indirect effects.

\begin{tabular}{cccccc}
\hline Parameter & Estimate & Lower & Upper & P & Hypothesis \\
\hline PI (China) $\leftarrow$ PI (Home) $\leftarrow$ PR & -0.062 & -0.141 & 0.019 & 0.114 & H7a (Not supported) \\
PI (China) $\leftarrow$ PI (Home $) \leftarrow$ PB & 0.498 & 0.374 & 0.655 & 0.009 & H7b (Supported) \\
\hline
\end{tabular}

PR: Perceived Risks, PB: Perceived Benefits, PI: Purchase Intention.

\section{Discussion}

In general, the results of this study are consistent with those of previous studies $[17,22,39,47-50]$ that show the links between knowledge and perceived risks (H1), knowledge and perceived benefits (H2), perceived risks, and purchase intention of RAPs made in the home country (H3), and perceived benefits and purchase intention of RAPs made in the home country (H4). Some studies hypothesized that product knowledge reduces the perceived risks (e.g., [64]). Fatimah et al. [65] found perceived quality and reliability gaps between new and RAPs among Indonesian consumers. According to a comprehensive risk theory [66], uncertainty about the outcome may be minimized by acquiring information and reducing uncertainty or delaying the purchase decision. In this study, however, we hypothesized that the more consumers know about RAPs, the greater their awareness of RAPs' potential risks. This hypothesis is supported because typical consumers may not be familiar with remanufactured parts [67]. Therefore, their perceived risks or potential losses 
in purchasing RAPs are higher even when their perceived product knowledge is greater. In consonance with previous research [13], this study also found that consumers' willingness to purchase, whether made domestically or in China, increases toward RAPs certified by reliable remanufacturers ( $\mathrm{H} 6 \mathrm{a}$ and $\mathrm{H} 6 \mathrm{~b})$.

Past research found an association between the purchase intention of RAPs remanufactured in the home country and consumers' risk and benefit perceptions. In this study, we hypothesized the association between purchase intention of RAPs "made in the home country" and those "made in China" (H5). The pace at which Chinese products are entering foreign markets has grown steadily over the years. China is already the world's largest exporting country, and its products are sold through the SEA markets. As of 2019, China serves as Indonesia's largest export and import market, indicating Indonesian consumers' certain degrees of familiarity and interest in Chinese products and brands. The positive link between the purchase intention of RAPs made in Indonesia and that of RAPs made in China found in this study encourages China to continue improving its national brand by focusing on product quality and developing a more robust and positive national image.

We proposed that perceived risks (X1) and benefits (X2) influence the purchase intention of RAPs made in China (Y) through the purchase intention of RAPs made in the home country (Indonesia) (M). This study observed partial mediation between X2 and Y via M $(\mathrm{H7b})$. That is, the mediating variable (M) accounts for some, but not all, of the relationship between $X$ and $Y$. Partial mediation implies that not only does a significant relationship exist between $\mathrm{M}$ and $\mathrm{Y}$, but also that some direct relationship exists between $\mathrm{X}$ and $\mathrm{Y}$. This study did not observe an indirect effect between X1 and Y via M (H7a). Although we observed the direct effect between $\mathrm{X} 1$ and $\mathrm{M}$, its coefficient magnitude was not large enough to observe the mediation (X1-M-Y). The weaker link between $\mathrm{X} 1$ and $\mathrm{M}$ may be explained by this study's respondents' lower functionality orientations. Atasu et al. [68] defined functionality-oriented customers as those who value remanufactured products and consider the quality of the product as being close to that of a new one; these customers also think that price must be offered at a lower rate. The results of $\mathrm{H7a}$ and $\mathrm{H7b}$ imply that by informing and educating Indonesian consumers about the remanufacturing process and remanufactured products, purchase intentions of RAPs made in China may be increased because we can expect consumers' understanding of actual characteristics of RAPs (e.g., relative to new parts, remanufactured parts do not pose a higher safety risk) to be enhanced.

Another explanation for our results in H7a (i.e., not supported) and H1 (i.e., not supported) is the "newness orientation" of consumers. Ratings on consumers' perceived risks (mean $=4.86$, significantly higher than the neutral point (4) of the scale, $p<0.001$; items such as "the quality and safety of RAPs are not as good as the new products" and "RAPs do not perform and function as well as new products") may indicate that consumers in this study are categorized as "newness-conscious customers" who equate quality with new products, not the remanufactured ones [68]. They perceive the remanufactured goods as lower in value than the new product simply because they do not meet their quality criteria of "newness." For these consumers, remanufacturers should discount the price of RAPs substantially [68].

In some SEA markets, consumers may regard Chinese brands as lesser quality and associate them with a lack of social responsibility and food scandals [69]. This study also confirmed SEA consumers' preferences toward RAPs made in their home country over those made in China, rating their purchase intentions of domestic RAPs significantly above the neutral point (4) of the scale. In contrast, those of Chinese RAPs are rated significantly below the neutral point (Table 3). The results offer some managerial implications for global Chinese remanufacturers. First, Chinese RAP manufacturers can counter the adverse effects of production location, or source effects, by masking or deemphasizing their foreign origins. Source effects occur when consumers in a foreign country perceive a bias against foreign firms or products [70]. Specifically, we recommend that Chinese RAP manufacturers evaluate their brand names in target markets in Asia carefully. This is an effective nation- 
branding strategy because the identity of "the country of origin represents the countryspecific advantages in precisely the same way that a brand name represents the firm-specific advantages" [71] (p. 85). Of course, one may argue that as long as the remanufacturers manage their manufacturing process well, the brand name's strength would offer them a competitive advantage. Therefore, source effects are irrelevant concerns. However, global firms such as Anheuser-Bush (U.S. firm) and Matsui (U.K. firm) intentionally used brand names in an attempt to create the nation branding illusion that their products are from Germany and Japan, respectively [72]. Second, Chinese RAP manufacturers can establish joint ventures with reputable RAP manufacturers, such as Bosch, Denso, Magna International, Continental, Aisin, Yazaki, and Cardone. Considering the challenges of establishing remanufacturing operations in SEA markets, we believe joint ventures that involve foreign direct investment in Asia are a great nation-branding strategic choice, considering the economic and political animosity against China. In the long run, as Chinese manufacturers may attempt to launch more RAPs labeled as "Made in China" in the region, efforts should be made to promote and maintain a high standard of quality for products from China.

\section{Conclusions}

This study conducted online surveys with 500 respondents in Indonesia to determine their perceptions of product knowledge, perceived risks and benefits, purchase intentions of RAPs remanufactured in the home country and China, and trust in the RAP certification. Previous studies explored and analyzed various marketing perspectives, including marketing strategies, consumer behaviors, pricing, and branding decisions. However, there seems to be a theoretical gap linking consumers' perceived images and purchase intentions of RAPs made in foreign countries. This study demonstrated that consumers' purchase intentions of RAPs made in foreign countries are influenced by the purchase intentions of RAPs made in the home country via their trust in certified RAPs. This study fills the theoretical gap in the remanufacturing management literature by focusing global marketing perspectives on examining the relationship between nation branding (i.e., country-of-origin), product certification, and purchase intentions.

The SEA region exhibited a combined GDP of \$3 trillion in 2019 and is one of the fastest-growing regional economies in the past decade [73]. The increased merchandise trade between members of the Association of Southeast Asian Nations (ASEAN) and China (e.g., $\$ 480$ billion in 2018 , or $17 \%$ of ASEAN's total merchandise trade) affirms their strong trade and economic relationships [73]. According to ASEAN [73], the largest external market for ASEAN exports in 2018 was China (14\%). Meanwhile, Indonesia is by far the largest economy in the ASEAN region, accounting for more than one-third of its GDP.

Like any other new entrant in the SEA market, China will face well-established competition against global remanufacturers. To gain market share in the SEA market, China should perform activities that improve the value of products deemed necessary by consumers. This is important not only because of the price aspect but also because of the establishment of "the value [US] consumers associate with a [Chinese] brand, as reflected in the dimensions of brand awareness, brand associations, perceived quality, and brand loyalty" [74] (p. 15). Consumers are hesitant to purchase or even consider purchasing an unfamiliar product; thus, entering foreign markets requires strong market support. Prospects with interest in a new product are unlikely to turn into actual buyers until they experience the comfort of familiarity. When consumers lack detailed knowledge of foreign products, the nation brand plays an essential role in evaluating and purchasing products. Various elements create the source country's images. For instance, how a government responds to pandemics (e.g., workers' mobility and containment policies), to some extent, may affect the image of the country. A government may even attempt to shield its market against products made in foreign countries with lax protective measures against pandemics. In this regard, government officials should understand and pay attention to nation branding to avoid the loss of brand reputation or enhance the country's brand equity. 
The nation brand may spillover from one product to another. A country with an established positive image (e.g., the U.S., Germany, and Japan) demonstrates substantial brand equity. However, suppose that a country demonstrates a negative or a mixture of positive and negative images; in that case, marketers must manage the product quality image because other products with a bad reputation may negatively influence the perception of the product they are trying to sell. China must improve its product and nation brand image and establish itself as a quality green manufacturer in the Asia-Pacific region.

In particular, FutureBrand Country Index [75] expresses concern for China's environmental issues due to its rapid economic progress. Undoubtedly, "made in China" has become a recognizable brand and noticeable label [76]. However, this label exhibits both positive and negative connotations [77]. For RAPs, the Chinese government has put efforts to promote the industry and the market. Circular Economy Promotion Law, enacted in 2008, defines government roles to promote remanufacturing. The Chinese government sets quality standards for RAPs and requires RAPs marketed in China to meet the standards. These policies effectively improve the quality and consumer images of RAPs, and it would be effective to apply them to export RAPs.

During the improvement process, Chinese remanufacturers may establish a strategy to prioritize markets with older demography and with more experience in using RAPs in the early stage and then move to other markets as the quality image improves. At this time, RAPs remanufactured in China are not favored over domestically made RAPs in the SEA countries. Fortunately, well-recognized Chinese companies, such as Alibaba, Baidu, Tencent, Huawei, Xiaomi, Nio, Xpeng, or BYD, can be used to promote China as an advanced, industrialized country. Chinese remanufacturers can consider a joint-venture with a foreign company in a developed nation that demonstrates a well-established name.

These research results provide important implications for global remanufacturers. In globalization and open borders, the distinction between domestic- and foreign-made products is becoming less relevant. According to Ohmae [78], "You do not worry about where the product was made ... All you care about is the product quality, price, design, value, and appeal to you as a consumer" (p. 144). This statement is correct if consumers know such marketing information cues. However, consumers often do not realize product quality, value, or even price, especially when they are not familiar with auto parts. Our study's results, the main effect of product quality and purchase intention, support past research that shows consumers still associate and evaluate product lines [54]. This leads to another implication for countries. To strengthen, change, or build their national image, governments are turning to professional image-marketers.

This study presents perceptions of SEA consumers toward RAPs made in China. The results reveal a need for Chinese remanufacturers to focus on extra efforts to improve its nation brand image. Understanding consumer needs and purchase processes are essential to building effective marketing strategies for the remanufacturing industry. Moreover, understanding how consumers go through need recognition (e.g., warranty and functionality), evaluation of alternatives (e.g., new vs. remanufactured; domestic vs. foreign; brand A vs. brand B), purchasing decision, and post-purchase behavior (e.g., satisfaction or dissatisfaction with parts), marketers in the industry can pick up cues from consumers.

We recommend Chinese remanufacturers or the remanufacturing industry to provide opportunities to increase consumers' understanding of the remanufacturing process and quality of remanufactured products in the SEA region. Even if consumers are characterized as newness-oriented and willing to pay more for a new product, their quality perceptions and purchase intentions may be changed over time if they accurately understand the actual quality of RAPs.

We acknowledge a major limitation to this study. Chinese remanufacturers will continue to play a significant role in developing the industry in the SEA region. The present research examined Indonesians' perceptions of RAPs made in China, assuming used automobile parts (i.e., cores) and finished products (i.e., RAPs in this study) move freely between importing and exporting countries. However, in reality, ASEAN members in- 
tervene in international trade to protect the interests of domestic producers, people, or groups. Therefore, future research should examine other factors apart from consumer perceptions that affect global remanufacturing operations. Based on our interviews with several remanufacturers of ink toners, home electronics products, and auto parts operating in the region, the critical marketing factors for remanufactured products are the consumers' acceptance of remanufactured products. Specifically, studies should examine policy factors in regional economic integration, including trade restrictions, barriers, and logistic challenges regarding the remanufacturing processes and products [68] because they influence remanufacturing effectiveness operations in the region. Although the authors are not aware of significant policy changes in the remanufacturing sector that would affect consumers' perceptions in Indonesia in the last five years, we remind readers that this research was a snapshot of Indonesian consumers in 2017.

Author Contributions: Conceptualization, K.C. and M.M.; methodology, K.C.; software, K.C.; validation, K.C.; formal analysis, K.C.; investigation, K.C. and M.M.; data curation, M.M.; writing-original draft preparation, K.C.; writing-review and editing, M.M.; project administration, K.C.; funding acquisition, M.M. All authors have read and agreed to the published version of the manuscript.

Funding: This research was funded by the Environmental Restoration and Conservation Agency (ERCA) of Japan, Project ID: JPMEERF16S11603 of the Environmental Research and Technology Development Fund.

Data Availability Statement: Not applicable.

Conflicts of Interest: The authors declare no conflict of interest.

\section{References}

1. Debo, L.; Toktay, L.; van Wassenhove, L. Market segmentation and product technology selection for remanufacturable products. Manag. Sci. 2005, 51, 1193-1205. [CrossRef]

2. Wilkins, J. The rise of remanufacturing. Ind. Today 2021. Available online: https://industrytoday.com/the-rise-ofremanufacturing/ (accessed on 17 February 2021).

3. Matsumoto, M.; Chinen, K.; Endo, H. Comparison of U.S. and Japanese consumers' perceptions of remanufactured auto parts. J. Ind. Ecol. 2016, 21, 966-979. [CrossRef]

4. UNEP (United Nations Environment Programme). Green Economy and Trade: Trends, Challenges and Opportunities. 2012. Available online: http:/ / wedocs.unep.org/handle/20.500.11822/8165 (accessed on 17 December 2020).

5. ASEAN Automotive Federation. Statistics. 2017. Available online: http://www.asean-autofed.com/files/AAF_Statistics_2017 .pdf (accessed on 17 December 2020).

6. Brzytwa, E.U.S. Views on Remanufacturing and Trade in Remanufactured Goods. In Proceedings of the Workshop on Remanufactured Goods. APEC Workshop on Remanufactured Goods, Kuala Lumpur, Malaysia, 22-23 October 2012; Available online: http:/ / mddb.apec.org/Documents/2012/MAG/WKSP2/12_mag_wksp2_013.pdf (accessed on 17 December 2020).

7. USITC (United States International Trade Commission). Remanufactured Goods: An Overview of the U.S. and Global Industries, Markets, and Trade. 2012. Available online: http://www.usitc.gov/publications/332/pub4356.pdf (accessed on 17 December 2020).

8. Persistence Market Research. Automotive Parts Remanufacturing Market: Global Industry Analysis $2013-2017$ and Forecast 2018-2026. 2019. Available online: https://www.persistencemarketresearch.com/market-research/automotive-partsremanufacturing-market.asp (accessed on 28 December 2020).

9. Statista. Automobile Production in China by Month 2019-2020. 2021. Available online: https://www.statista.com/statistics/2769 38/automobile-production-in-china-by-month/\#statisticContainer (accessed on 9 February 2021).

10. APRA (Automotive Parts Remanufacturers Association). Remanufacturing Global Outlook, Duxes' 6th China Remanufacturing Summit. Beijing, China. 2016. Available online: https://cdn.ymaws.com/apra.org/resource/resmgr/Events/6th_China_ Reman_Summit_5-27-.pdf (accessed on 15 November 2020).

11. Macrotrends. China GDP Growth Rate 1961-2021. 2021. Available online: https://www.macrotrends.net/countries/CHN/ china/gdp-growth-rate (accessed on 9 February 2021).

12. Kotler, P.; Keller, K.L. Marketing Management, 15th ed.; Pearson: London, UK, 2014.

13. Matsumoto, M.; Chinen, K.; Endo, H. Remanufactured auto parts market in Japan: Historical review and factors affecting green purchasing behavior. J. Clean. Prod. 2018, 172, 4494-4505. [CrossRef]

14. Steinhilper, R. Remanufacturing: The Ultimate Form of Recycling; Fraunhofer IRB Verlag: Stuttgart, Germany, 1998.

15. Abbey, J.D.; Meloy, M.G.; Guide, V.D.R.; Atalay, S. Remanufactured products in closed-loop supply chains for consumer goods. Prod. Oper. Manag. 2015, 24, 488-503. [CrossRef] 
16. Jiménez-Parra, B.; Rubio, S.; Vicente-Molina, M.A. Key drivers in the behaviour of potential consumers of remanufactured products: A study on laptops in Spain. J. Clean. Prod. 2014, 85, 488-496. [CrossRef]

17. Michaud, C.; Llerena, D. Green consumer behavior: An experimental analysis of willingness to pay for remanufactured products. Bus. Strategy Environ. 2011, 20, 408-420.

18. Hazen, B.T.; Overstreet, R.E.; Jones-Farmer, L.A.; Field, H.S. The role of ambiguity tolerance in consumer perception of remanufactured products. Int. J. Prod. Econ. 2012, 135, 781-790. [CrossRef]

19. Wang, Y.; Wiegerinck, V.; Krikke, H.; Zhang, H. Understanding the purchase intention towards remanufactured product in closed-loop supply chains: An empirical study in China. Int. J. Phys. Distrib. Logist. Manag. 2013, 43, 866-888. [CrossRef]

20. Sundin, E.; Ostlin, J.; Bjorkman, M. Why is remanufacturing more successful in the United States than in Sweden? In Proceedings of the 15th CIRP International Conference on Life Cycle Engineering, Sydney, Australia, 17-19 March 2008; pp. $247-251$.

21. Wang, Y.; Huscroft, J.R.; Hazen, B.T.; Zhang, M. Green information, green certification and consumer perceptions of remanufactured automobile parts. Resour. Conserv. Recycl. 2018, 128, 187-196. [CrossRef]

22. Milios, L.; Matsumoto, M. Consumer perception of remanufactured automotive parts and policy implications for transitioning to a circular economy in Sweden. Sustainability 2019, 11, 6264. [CrossRef]

23. Matsumoto, M.; Chinen, K.; Jamaludin, K.R.; Yusoff, B.S.M. Barriers for remanufacturing business in Southeast Asia: The role of governments in circular economy. In EcoDesign and Sustainability I; Kishita, Y., Matsumoto, M., Inoue, M., Fukushige, S., Eds.; Springer: Singapore, 2021; pp. 151-161.

24. Krugman, P. Does the new trade theory require a new trade policy? World Econ. 1992, 15, 423-441. [CrossRef]

25. Anholt, S. Competitive identity. In Destination Brands: Managing Place Reputation, 3rd ed.; Morgan, N., Pritchard, A., Pride, R., Eds.; Elsevier: Burlington, MA, USA, 2011.

26. Nakra, P. Should You Care about Country of Origin Impact? International Business Training. Available online: https://www. shippingsolutions.com/blog/should-you-care-about-country-of-origin-impact (accessed on 15 December 2020).

27. Van Ham, P. The rise of the brand state: The postmodern politics of image and reputation. Foreign Aff. 2001, 80, 2-6. [CrossRef]

28. Ajzen, I. From intentions to actions: A theory of planned behavior. In Action-Control: From Cognition to Behavior; Kuhl, J., Beckman, J., Eds.; Springer: Heidelberg, Germany, 1985; pp. 11-39.

29. Darling, J.R.; Arnold, D.R. The competitive position abroad of products and marketing practices of the United States, Japan, and selected European countries. J. Consum. Mark. 1998, 5, 61-68. [CrossRef]

30. Hsieh, M.H. An investigation of country-of-origin effect using correspondence analysis, a cross-national context. Int. J. Mark. Res. 2004, 46, 267-295. [CrossRef]

31. Hui, M.K.; Zhou, L. Linking product evaluations and purchase intention for country-of-origin effects. J. Glob. Mark. 2002, 15, 95-101. [CrossRef]

32. Klein, J.G. Us versus them, or us versus everyone? Delineating consumer aversion to foreign goods. J. Int. Bus. Stud. 2002, 33, 345-363. [CrossRef]

33. Newman, C.L.; Turri, A.M.; Howlett, E.; Stokes, A. Twenty years of country-of-origin food labeling research: A review of the literature and implications for food marketing systems. J. Macromark. 2014, 34, 505-519. [CrossRef]

34. Thøgersen, J.; Pedersen, S.; Paternoga, M.; Schwendel, E. How important is country-of-origin for organic food consumers? Review of the literature and suggestions for future research. Br. Food J. 2016, 119, 542-557. [CrossRef]

35. Hamzaoui-Essoussi, L.; Linton, J.D. Offering branded remanufactured/recycled products: At what price? J. Remanuf. 2014, 4, 1-15. [CrossRef]

36. Matsumoto, M.; Chinen, K.; Endo, H. Paving the way for sustainable remanufacturing in Southeast Asia: An analysis of auto parts markets. J. Clean. Prod. 2018, 205, 1029-1041. [CrossRef]

37. Dacin, P.A.; Mitchell, A.A. The measurement of declarative knowledge. Adv. Consum. Res. 1986, 13, 454-459.

38. Wang, Y.; Hazen, B.T. Consumer product knowledge and intention to purchase remanufactured products. Int. J. Prod. Econ. 2016, 181, 460-469. [CrossRef]

39. Hauser, W.; Lund, R.T. Remanufacturing: An American Resource; Boston University: Boston, MA, USA, 2003.

40. Kim, H.; Raichur, V.; Skerlos, S.J. Economic and environmental assessment of automotive remanufacturing: Alternator case study. In Proceedings of the 2008 International Manufacturing Science and Engineering Conference (MSEC 2008), Evanston, IL, USA, 7-10 October 2008; pp. 1-8.

41. Quariguasi-Frota-Neto, J.; Bloemhof, J. An analysis of the eco-efficiency of remanufactured personal computers and mobile phones. Prod. Oper. Manag. 2012, 21, 101-114. [CrossRef]

42. Gutowski, T.G.; Sahni, S.; Boustani, A.; Graves, S.C. Remanufacturing and energy savings. Environ. Sci. Technol. 2011, 45, 4540-4547. [CrossRef] [PubMed]

43. Brothers, E. Reman options. Fleet Equip. 2008, 34, 54.

44. McConocha, D.M.; Speh, T.W. Remarketing: Commercialization of remanufacturing technology. J. Bus. Ind. Mark. 1991, 6, 23-37. [CrossRef]

45. Ayres, R.; Ferrer, G.; Van Leynseele, T. Eco-efficiency, asset recovery and remanufacturing. Eur. Manag. J. 1997, 15, 557-574. [CrossRef]

46. Serafeim, G. Social-impact efforts that create real value. Harvard Business Review. 2020. Available online: https://hbr.org/2020/0 9/social-impact-efforts-that-create-real-value (accessed on 28 December 2020). 
47. Guide, V.D.R.; Li, J. The potential for cannibalization of new products sales by remanufactured products. Decis. Sci. 2010, 41, 547-572. [CrossRef]

48. Harms, R.; Linton, J.D. Willingness to pay for eco-certified refurbished products: The effects of environmental attitudes and knowledge. J. Ind. Ecol. 2015, 20, 893-904. [CrossRef]

49. Hamzaoui-Essoussi, L.; Linton, J.D. New or recycled products: How much are consumers willing to pay? J. Consum. Mark. 2010, 27, 458-468. [CrossRef]

50. Abbey, J.D.; Kleber, R.; Souza, G.C.; Voigt, G. The role of perceived quality risk in pricing remanufactured products. Prod. Oper. Manag. 2017, 26, 100-115. [CrossRef]

51. Guiot, D.; Roux, D. A second-hand shoppers' motivation scale: Antecedents, consequences, and implications for retailers. J. Retail. 2010, 86, 355-371. [CrossRef]

52. Vertinsky, I.; Zhou, D. Product and process certification—Systems, regulations and international marketing strategies. Int. Mark. Rev. 2000, 17, 231-252. [CrossRef]

53. Kotler, P. Marketing Management: Analysis, Planning, Implementation, and Control; Prentice-Hall: Upper Saddle River, NJ, USA, 1994.

54. Jaffe, E.D.; Nebenzahl, I.D. National Image and Competitive Advantage: The Theory and Practice of Place Branding; Copenhagen Business School Press: Copenhagen, Denmark, 2006.

55. Nagashima, A. Minnesota Businessmen's Image of Foreign Made Products by Semantic Differential Method. Master's Thesis, University of Minnesota, Twin Cities, MN, USA, 1965.

56. Chinen, K. The Relationships between Total Quality Management Factors and Work Outcomes in a Maquiladora. Ph.D. Thesis, New Mexico State University, Las Cruces, NM, USA, 2000.

57. Imai, M. Kaizen: The Key to Japan's Competitive Success; McGraw-Hill Education: New York, NY, USA, 1986.

58. Frost \& Sullivan. Will China Become the Future Destination for Remanufacturing of Automotive Parts? Available online: https: //ww2.frost.com/frost-perspectives / will-china-become-the-future-destination-for-remanufacturing-of-automotive-parts / (accessed on 17 December 2020).

59. Guidat, T.; Seidel, J.; Kohl, H.; Seliger, G. A comparison of best practices of public and private support incentives for the remanufacturing industry. Procedia Cirp 2017, 61, 177-182. [CrossRef]

60. USAID (United States Agency for International Development). Remanufacturing in Malaysia-An assessment of the current and future remanufacturing industry. In Proceedings of the APEC (Asia-Pacific Economic Cooperation) 48th Market Access Group Meeting, Clark, Philippines, 1 February 2015. Available online: https://www.ncapec.org/docs/USAID $\% 20$ Study $\% 20$ on $\% 20$ Malaysian\%20Remanufacturing.pdf (accessed on 15 November 2020).

61. Brislin, R.W. Translation and content analysis of oral and written material. In Handbook of Cross-Cultural Psychology: Methodology; Triandis, H.C., Berry, J.W., Eds.; Allyn and Bacon: Boston, MA, USA, 1980; pp. 389-444.

62. Fornell, C.; Larcker, D. Structural equation models with unobservable variables and measurement error. J. Mark. Res. 1981, 18, 39-50. [CrossRef]

63. Falk, R.; Miller, N. A Primer Soft Modeling; University of Akron Press: Akron, OH, USA, 1992.

64. Nepomuceno, M.V.; Laroche, M.; Richard, M.-O. How to reduce perceived risk when buying online: The interactions between intangibility, product knowledge, brand familiarity, privacy and security concerns. J. Retail. Consum. Serv. 2014, 21, 619-629. [CrossRef]

65. Fatimah, Y.A.; Biswas, W.; Mazhar, I.; Islam, M.N. Sustainable manufacturing for Indonesian small and medium-sized enterprises (SMEs): The case of remanufactured alternators. J. Remanuf. 2013, 3, 1-13. [CrossRef]

66. Taylor, J.W. The role of risk in consumer behavior. J. Mark. 1974, 38, 54-60.

67. Chen, Y.; Wang, J.; Jia, X. Refurbished or remanufactured? An experimental study on consumer choice behavior. Front. Psychol. 2020. [CrossRef]

68. Atasu, A.; Guide, V.D.R.; Van Wassenhove, L.N. So what if remanufacturing cannibalizes my new product sales? Calif. Manag. Rev. 2010, 52, 1-21. [CrossRef]

69. Mei-Fang, C. Segmentation of Taiwanese consumers based on trust in the food supply system. Br. Food J. 2012, 114, 70-84 [CrossRef]

70. Chinen, K.; Sun, Y. Effects of country-of-origin on buying behavior: A study of the attitudes of United States consumers to Chinese-brand automobiles. Int. J. Manag. 2011, 28, 553-563.

71. Johansson, J.K. Missing a strategic opportunity: Managers' denial of country-of-origin effects. In Product-Country Images: Impact and Role in International Marketing; Papadopoulos, N., Heslop, L.A., Eds.; International Business Press: Binghamton, NY, USA, 1993; pp. 77-86.

72. Harris, T. Current and future changes in corporate attitudes to national identity. Thunderbird Int. Bus. Rev. 2002, 44, 165-174. [CrossRef]

73. ASEANSTATS. ASEAN Key Figures 2019. Available online: https://www.aseanstats.org/wp-content/uploads/2019/11/ ASEAN_Key_Figures_2019.pdf (accessed on 17 December 2020).

74. Aaker, D.A. Managing Brand Equity; The Free Press: New York, NY, USA, 1991.

75. FutureBrand Country Index 2019. Available online: https://www.futurebrand.com/uploads/FCI/FutureBrand-Country-Index2019.pdf (accessed on 17 December 2020). 
76. Lyles, M.A.; Flynn, B.B.; Frohlich, M.T. All supply chains don't flow through: Understanding supply chain issues in product recalls. Manag. Organ. Rev. 2008, 4, 167-182. [CrossRef]

77. Loo, T.; Davies, G. Branding China: The ultimate challenge in reputation management? Corp. Reput. Rev. 2006, 9, 198-210. [CrossRef]

78. Ohmae, K. The global logic of strategic alliances. Harv. Bus. Rev. 1989, 3, 143-154. 